This work was funded by a grant from the research support group of the Greater Glasgow Health Board.

1 Jarvis G, Hall S, Stamp S, Millar D, Johnson A. An assessment of urodynamic examination in incontinent women. Br $\mathcal{F}$ Obstet Gynaecol 1980;87:893-6.

2 Bates CP, Loose H, Stanton SL. The objective study of incontinence after repair operations. Surg Gynecol Obstet 1973;136:17-22.

3 Huskisson EC. Measurement of Pain. Lancet 1974;ii:1127-31.

4 Walter S, Vejlsgaard R. Diagnostic catheterisation and bacteruria in women with urinary incontinence. Br f Urol 1978;50:106-8.

5 Frewen WK. An objective assessment of the unstable bladder of psychosomatic origin. $\mathrm{Br} \mathcal{J}$ Urol 1978;50:246-9.

(Accepted 9 May 1986)

Department of Gynaecology, Stobhill General Hospital, Glasgow

D E PARKIN, MB, MRCOG, research registrar

J A DAVIS, MB, MRCOG, consultant gynaecologist

Correspondence to: Dr D E Parkin.

\section{A case of scurvy}

Sporadic cases of scurvy may continue to occur despite improved standards of living and food supply. Those at risk include people living alone and those with peculiar dietary habits, which are often taken to relieve symptoms. We report a case of scurvy in a young man whose diet was severely deficient in vitamin $\mathrm{C}$ as a result of exclusions devised to prevent alleged hypersensitivity to food. Current lay enthusiasm for dietary treatment of a great variety of symptoms may well lead to an increase in this type of deficiency. ${ }^{12}$

\section{Case report}

A 28 year old man, educationally below average, presented as an emergency with malaise, immobility, and a rash. Three years previously he had been referred for investigation of epilepsy, which had been diagnosed 14 years before. His parents, with whom he lived, had become convinced that his fits were due to food allergy, which they also blamed for his intermittent attacks of flatulence. Temporal lobe epilepsy had been diagnosed, and concurrent investigation for coeliac disease (including small intestinal biopsy) yielded negative results.

He was advised to eat normally, but his parents remained determined to prove

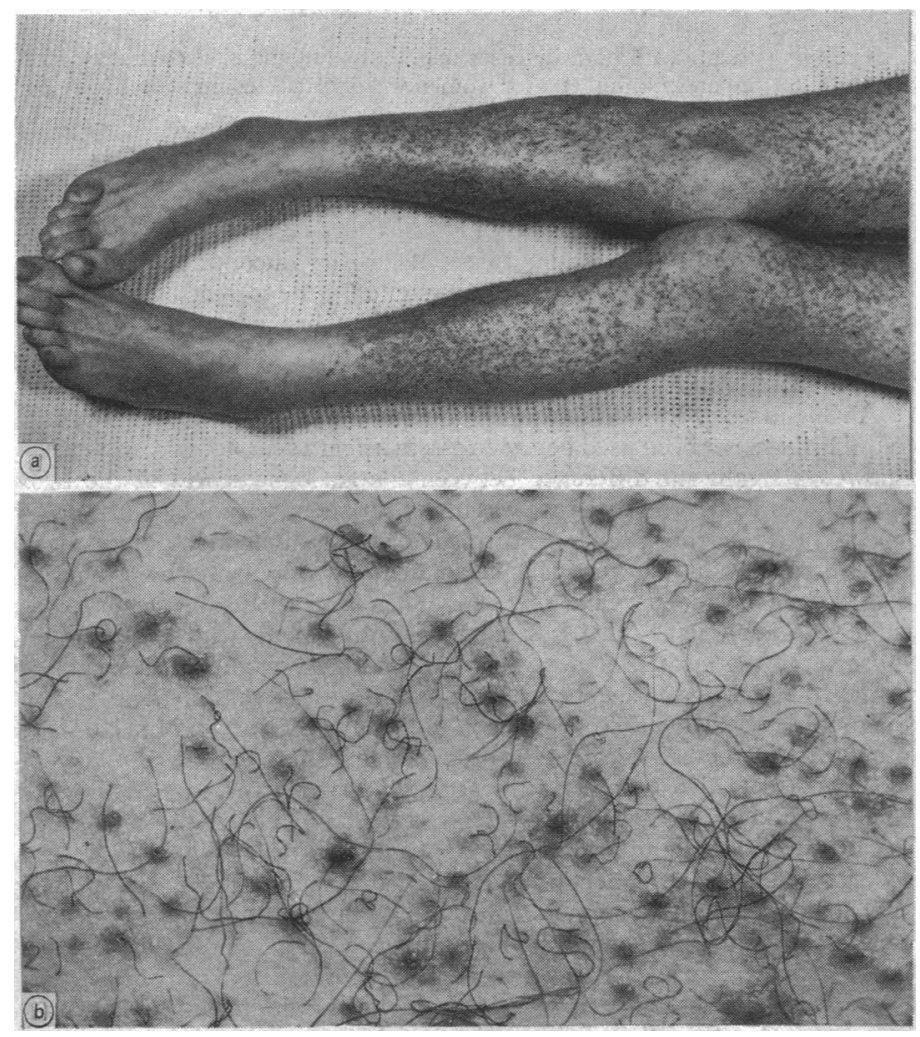

Pronounced petechial rash $(a)$ and corkscrew hairs $(b)$. that he suffered from food allergy. To this end he consulted many practitioners, each of whom added different advice and fresh exclusions to his dwindling diet. A few months before admission he attended an alternative medicine clinic, which excluded all potatoes, oranges, and lemons on the unsupported grounds of allergy. No advice seems to have been given about vitamin intake. His mother was strict with these exclusions, so that on admission his diet consisted of only eight foodstuffs: gluten free bread, rice cakes, vegetable margarine, apple juice, steamed white cod, brown rice, yeast pâté, and occasional portions of green vegetables. His daily intake with this diet was protein $62 \mathrm{~g}$, fat $66 \mathrm{~g}$, and carbohydrate $305 \mathrm{~g}(8 \cdot 8 \mathrm{MJ} ; 2095 \mathrm{kcal})$. His daily intake of vitamin C was $10.2 \mathrm{mg}$ (recommended daily intake $30 \mathrm{mg}^{3}$ ), of iron $13.4 \mathrm{mg}$, and of folate 7.7 $\mu \mathrm{g}$.

He gave a two month history of increasing fatigue, difficulty in walking, pallor, and a rash over his buttocks and legs, which in the days before his admission had become pronounced (figure) with painful swelling of both knees, ankles, and elbows. There had been one episode of haemoptysis but no overt gastrointestina bleeding. On examination he was pale and thin and had a widespread petechial rash over both buttocks and lower abdomen, with tiny corkscrew hairs. Recent bleeding from the gums was visible, and fresh tender bruising was present behind the knees and ankles, indicating bleeding around these joints.

Investigation showed haemoglobin concentration $84 \mathrm{~g} / 1$, white cell count $5 \cdot 1 \times 10^{9} / 1$, mean corpuscular volume $83 \mathrm{fl}$, and serum $B_{12}$ concentration $153 \mathrm{ng} / \mathrm{l}$; leucocyte ascorbic acid concentrations were too low for accurate measurement. Other investigations, including chest $x$ ray examination, yielded normal results. He made a dramatic recovery, being able to walk within 48 hours after receiving oral vitamin $\mathrm{C}$. He subsequently took vitamin supplements and remained well.

\section{Comment}

Adult scurvy commonly presents with fatigue, weight loss, arthralgia, depression, and weakness. ${ }^{4}$ There is a tendency to bleed, with swollen, friable gums, loosening of the teeth, and perifollicular haemorrhages. Other features include associated anaemia and corkscrew hairs. Our patient's die was grossly deficient in vitamin $\mathrm{C}$ because of his parents' conviction that he had a food allergy. There is widespread interest in alternative medicine, in which dietary exclusions may feature. ${ }^{1}$ Our patient shows the harm that may come from this; as scurvy is uncommon, delay in diagnosis may occur. Indeed, patients with scurvy may die suddenly without warning from cardiac failure. ${ }^{5}$ Doctors therefore need to have a heightened index of suspicion for deficiencies when patients are following exclusion diets, for whatever reason.

1 May CD. Food sensitivity: facts and fallacies. Nutr Rev 1984;42:72-8.

2 Royal College of Physicians and British Nutrition Foundation. Food intolerance and food aversion. $f R$ Coll Physicians (Lond) 1984;18:83-123.

3 Committee on Medical Aspects of Food Policy. Recommended daily amounts of food, energy, and nutrients for groups of people in the UK. London: HMSO, 1979.

4 Reuler JB, Broudy VC, Cooney TG. Adult scurvy. JAMA 1985;253:805-7.

5 Sament S. Cardiac disorders in scurvy. N Engl 7 Med 1970;282:282-3.

(Accepted 19 May 1986)

Queen Alexandra Hospital, Portsmouth

M HUGHES, MB, BS, house physician

N CLARK, MB, BS, house physician

L FORBES, BSC, SRD, chief dietitian

D G COLIN-JONES, MD, FRCP, consultant physician

Correspondence to: Dr Colin-Jones.

\section{Diabetic renal disease: differences between Asian and white patients}

A recent survey by the World Health Organisation suggested that ethnic differences might result in differences in the prevalence of small vessel disease in diabetics. ${ }^{1}$ We undertook this study to determine whether the prevalence of diabetic nephropathy differed between Asian and white patients attending the Leicester diabetic clinic.

\section{Patients, methods, and results}

We studied 370 consecutive Asian and 368 consecutive white patients who had attended the diabetic clinic for at least one year (table). Patients were regarded as Asian if they originated from the Indian subcontinent (India, Pakistan, Bangladesh, and Sri Lanka). Proteinuria was considered to be present if Albustix testing of urine on at least two occasions at least six weeks apart yielded positive results, 24 hour protein excretion was $>0.5 \mathrm{~g}$, and there was no urinary tract infection or evidence of disease of the renal tract on intravenous pyelography. Retinopathy 